Tersedia online di: http://ejournal-balitbang.kkp.go.id/index.php/bawal
e-mail:bawal.puslitbangkan@gmail.com
BAWAL wIDYA RISET PERIKANAN TANGKAP
Volume 10 Nomor 3 Desember 2018
p-ISSN: 1907-8226
e-ISSN: 2502-6410
BAWAL
Nomor Akreditasi Kementerian RISTEKDIKTI: 21/E/KPT/2018

\title{
BIOLOGI REPRODUKSI SELAR BENTONG (Selar crumenophthalmus Bloch, 1793) DI PERAIRAN KWANDANG, GORONTALO UTARA
}

\section{BIOLOGICAL REPRODUCTION OF BIGEYE SCAD (Selar crumenopthalmus Bloch, 1793) IN KWANDANG WATERS, NORTH GORONTALO}

\author{
Umi Chodrijah*1 dan Ria Faizah ${ }^{2}$ \\ ${ }^{1}$ Peneliti pada Balai Riset Perikanan Laut - Jl. Raya Bogor KM 47, Nanggewer- Cibinong, Bogor, Jawa Barat, Indonesia \\ ${ }^{2}$ Peneliti pada Pusat Riset Perikanan -Gedung Balitbang KP II, J1. PAsir Putih 2 Ancol Timur, Jakarta Utara, Indonesia \\ Teregistrasi I tanggal: 07 Desember 2016; Diterima setelah perbaikan tanggal: 09 Januari 2018; \\ Disetujui terbit tanggal: 25 Januari 2018
}

\begin{abstract}
ABSTRAK
Ikan selar bentong (Selar crumenophthalmus Bloch, 1793) merupakan salah satu ikan ekonomis penting yang tertangkap di perairan Kwandang, Sulawesi Utara. Penelitian ini bertujuan untuk mengetahui biologi reproduksi ikan selar bentong. Pengumpulan data panjang berat, jenis kelamin dan tingkat kematangan gonad dilakukan dari periode Februari hingga November 2017. Jumlah contoh ikan yang diamati sebanyak 3.820 ekor. Hasil penelitian ini diperoleh persamaan hubungan panjang-berat ikan selar bentong yang diukur yaitu $\mathrm{W}=$ $0,0092 \mathrm{~L}^{3,1857}$. Nilai b dari persamaan ini adalah 3,18 yang mengindikasikan bahwa pola pertumbuhannya bersifat isometrik. Ukuran pertama kali matang gonad $(\mathrm{Lm})$ adalah 17,69 cmFL. Rasio kelamin antara betina terhadap jantan yaitu $1: 1,2$. Musim pemijahan diduga terjadi antara bulan November-Ferbuari dan bersifat multiple spawner.
\end{abstract}

Kata Kunci: Biologi reproduksi; selar bentong; Kwandang

\section{ABSTRACT}

Bigeye scad (Selar crumenophthalmus Bloch, 1793) was one of the important economic species in the artisanal fishery in Kwandang waters North, Sulawesi. The aim of this study was to determine the biological reproduction of big eye scad in the Kwandang waters, Sulawesi Sea. Data collection of lengths and weights, sex, and the gonad maturity stage were done between January-November 2016. A total of 3820 specimens was collected al together and examined in the study. The result showed that length-weight relationship for big eye scad were $W=0,0092 L^{3,1857}$. The exponent values ( $b$ slope) of length-weight relationship of big eye scad was 3,185 indicating isometric growth pattern. The length at first maturity $(\mathrm{Lm})$ for bigeye scad was $17,69 \mathrm{cmFL}$. The sex-ratio between female and male was $1: 1.2$. The spawning season was estimated between November and February (multiple spawner).

Keywords: Biology reproduction; bigeye scad, Kwandang 


\section{PENDAHULUAN}

Salah satu ikan pelagis kecil yang bernilai ekonomis penting adalah ikan selar bentong (Selar crumenophthalmus). Jenis ikan ini merupakan satu jenis selar dari anggota Carangidae yang aktif mencari makan di malam hari (nocturnal) Widodo et al. (1993). Menurut Kimura (2011), ikan selar bersifat ikan karnivora dengan mangsa berupa larva ikan dai famili Clupeidae, Balastidae, Cephalopoda, Serranidae, sute larva kepiting. Ikan selar banyak tertangkap di perairan pantai serta hidup berkelompok sampai kedalaman 80m (Djuhanda dalam Hidayat, 2005). Tingginya permintaan ikan selar dari masyarakat dengan harga yang cukup tinggi dapat mendorong meningkatkan upaya penangkapan jenis ikan ini.

Perairan Kwandang merupakan bagian dari Laut Sulawesi (WPP-NRI 716) dan merupakan wilayah penangkapan ikan selar bentong (S. crumenophthalmus) di Provinsi Gorontalo. Pada tahun 2011-2015 rata-rata produksi ikan selar bentong sebanyak 210.025 ton per tahun atau $8,11 \%$ dari total tangkapan pelagis kecil di Kwandang (PPN Kwandang, 2016).

Penelitian ikan pelagis di perairan Indonesia telah banyak dilakukan, namun khusus ikan selar masih sedikit terutama terkait dengan biologinya. Penelitian ikan selar bentong diperairan Semarang oleh Siwat et al. (2016) diperoleh panjang asimtotik 23,8 cmFL. Peneliti Zamroni \& Suwarso (2011) menyatakan nilai pertama kali matang gonad (Lm) ikan selar bentong di Laut Banda adalah 21,85 cmFL. Faizah et al. (2014), menyatakan bahwa pemanfaatan ikan bentong di perairan Kwandang terindikasi telah mencapai tingkat optimum. Penelitian ini merupakan update dari penelitian sebelumnya, yaitu evaluasi status pemanfaatan selar bentong dari tahun ke tahun sehingga dapat dimanfaatkan secara berkelanjutan.

Tujuan dari penelitian ini adalah untuk mengetahui informasi biologi reproduksi ikan selar yang ditangkap di perairan Laut Sulawesi dan didaratkan di Pelabuhan Perikanan Nusantara (PPN) Kwandang Gorontalo Utara. Manfaat dari penelitian ini adalah untuk memberikan informasi tentang kondisi biologi sumberdaya ikan selar bentong sehingga dapat dijadikan rujukan untuk kebijakan pemanfaatan sumberdaya secara berkelanjutan.

\section{BAHANDANMETODE \\ Waktu, Lokasi dan Jenis Data}

Penelitian selar bentong dilakukan di Pelabuhan Perikanan Nusantara (PPN) Kwandang, Gorontalo Utara (Gambar 1) pada bulan Februari-November 2016. Data yang dikumpulkan meliputi panjang dan berat ikan, jenis kelamin, tingkat kematangan gonad (TKG) dan sampel telur ikan.

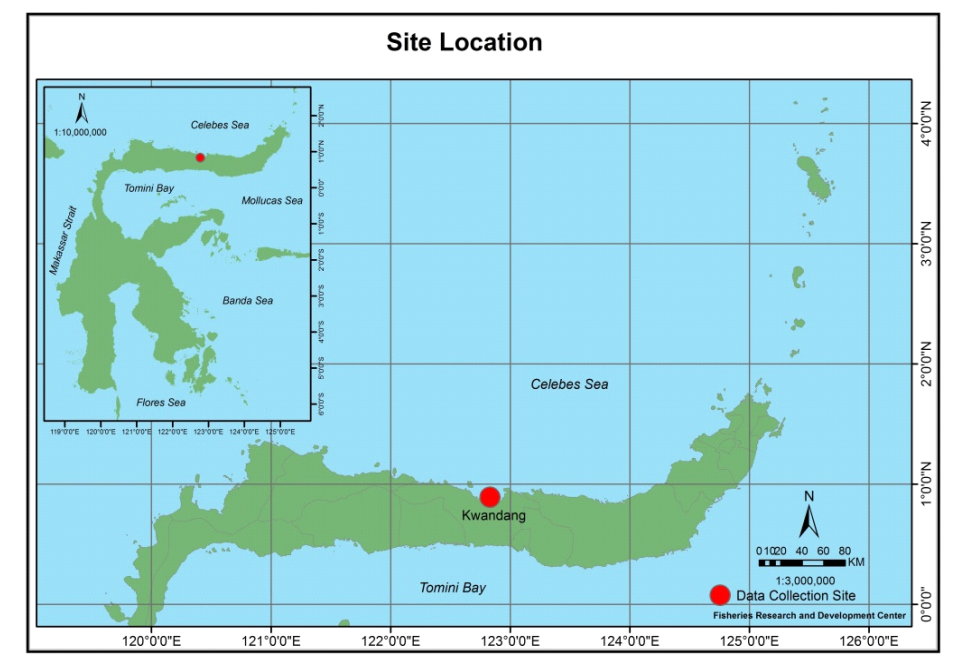

Gambar 1. Peta lokasi penelitian di Pelabuhan Perikanan Kwandang Gorontalo Utara.

Figure 1. Map showing sampling site in Kwandang Fishing Port-North Gorontalo..

\section{Prosedur Pengambilan Sampel Ikan}

Pengukuran panjang ikan dilakukan setiap bulan selama periode Januari hingga November dibantu oleh enumerator. Jumlah sampel ikan sebanyak 3.820 ekor diperopeh dari hasil tangkapan bagan (lift net) dan pancing ulur (hand line). Masing-masing sampel ikan diukur panjang cagaknya (FL) menggunakan papan ukur dengan ketelitian 0,5 cm. Untuk mendapatkan gonad ikan, dilakukan pembedahan. Gonad kemudian dibersihkan dan dikeringkan menggunakan tisu, selanjutnya ditimbang dan diawetkan dengan larutan Gilson.

TKG diamati secara visual dengan melihat perubahan morfologi gonad sesuai dengan kriteria Holden \& Raitt (1974) sebagai berikut: 
1. Tahap awal: ovarium seperti benang, permukaan licin.

2. Tahap berkembang: ovarium lebih besar, telur belum terlihat dengan mata.

3. Mulai matang: gonad berwarna kuning, tampak butiran telur dan saluran darah.

4. Matang: ovarium makin besar, bentuknya bening seperti agar, mengisi 1/2,2/3, sampai mencapai ukuran maksimum (fully developed gonad) yang siap memijah.

5. Memijah sampai spent: ovarium berkerut karena telur berangsur-angsur dilepaskan, sampai setengah dari ruang badan. Ovarium berisi sisa pelepasan butir-butir telur yang opaque dan sudah matang.

\section{Analisis Data \\ Hubungan Panjang-Berat}

Model allometric linear (LAM) digunakan untuk menghitung parameter a dan b melalui pengukuran perubahan berat dan panjang. Koreksi bias pada perubahan berat rata-rata dari unit logaritma digunakan untuk memprediksi berat pada parameter panjang sesuai dengan persamaan allometric berikut, (DeRobert \& William(2008).:

$\mathrm{W}=\mathrm{a} \mathrm{L}^{\mathrm{b}}$

Dimana $\mathrm{W}$ adalah berat ikan $(\mathrm{g}), \mathrm{L}$ adalah panjang cagak ikan $(\mathrm{cm})$, a dan $\mathrm{b}$ adalah parameter pertumbuhan. Persamaan ini dapat diselesaikan melalui transformasi linear logaritme dalam bentuk $\log \mathrm{W}=\log \mathrm{a}+\mathrm{b} \log \mathrm{L}$.

Untuk mengetahui apakah pertumbuhan ikan tergolong isometrik atau alometrik dilakukan uji-t nilai b terhadap 3. Dengan hipotesis sebagai berikut:

H0 : Nilai $b=3$, sehingga pertumbuhan bersifat Isometrik $\mathrm{H} 1$ : Nilai $\mathrm{b} \neq 3$, sehingga pertumbuhan bersifat allometrik

Jika $b=3$, maka pertumbuhannya isometrik, yaitu tingkat pertumbuhan panjang, lebar dan tinggi ikan adalah sama (Everhart \& Youngs, 1981). Jika tidak sama dengan 3 , pertumbuhannya allometrik, yaitu allometrik positif apabila $\mathrm{b}>3$ dan allometrik negatif apabila $\mathrm{b}<3$.

thitung $=\frac{b_{1}-b_{0}}{S b_{1}}$

$S b_{1}=\sqrt[2]{\frac{1}{n-2}\left(\left(\frac{s y}{s x}\right)^{2}-b 0^{2}\right)}$

dimana:

$\mathrm{b}_{1}=$ nilai $\mathrm{b}$ dari hubungan panjang berat

$b_{0}=3$

$\mathrm{Sb}_{1}=$ simpangan koefisien $\mathrm{b}$.

\section{Rasio Kelamin}

Pengujian rasio kelamin dilakukan dengan uji- Chi Kuadrat (Steel \& Torrie, 1989):

$$
X^{2}=\sum_{i=1} \frac{(O i-e i)^{2}}{e i}
$$

dimana:

Oi = jumlah frekuensi ikan jantan dan betina

ei $=$ jumlah ikan jantan dan betina harapan ke-i

Jika $\mathrm{X}^{2}$ hitung lebih kecil daripada $\mathrm{X}^{2}$ tabel, maka Hipotesis nol (Ho) diterima, artinya seimbang, namun jika $\mathrm{X}^{2}$ hitung lebih besar daripada $\mathrm{X}^{2}$ tabel, maka Hipotesis nol (Ho) ditolak, artinya rasio kelamin tidak seimbang.

\section{Panjang Pertama Kali Matang Gonad (Lm)}

Pendugaan panjang pertama kali matang gonad (lengthat first maturity) menggunakan rumus berdasarkan Udupa (1986):

$\mathrm{m}=\mathrm{Xk}+\mathrm{X} / 2-(\mathrm{XPi})$

dimana:

$\mathrm{m}=\log$ ukuran ikan saat pertama matang gonad

$\mathrm{Xk}=\log$ ukuran ikan dimana $100 \%$ ikan sampel sudah matang

$\mathrm{X}=$ selang log ukuran (log size increment)

$\mathrm{Pi}=$ proporsi ikan matang pada kelompok ke-i

Rata-rata ukuran ikan pertama matang gonad diperoleh dari nilai $\operatorname{antilog}(\mathrm{m})$.

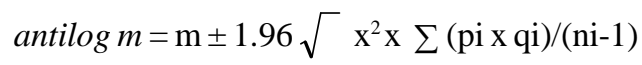

\section{Indeks Kematangan Gonad}

Untuk menentukan Indeks Kematangan Gonad (IKG) digunakan rumus Effendie (1979):

$$
\mathrm{IKG} \%=\frac{W g}{W} x 100
$$

dimana:

$\mathrm{W}=$ berat ikan (gram)

$\mathrm{Wg}=$ berat $\operatorname{gonad}($ gram$)$

\section{Fekunditas}

Fekunditas diasumsikan sebagai jumlah telur yang terdapat dalam ovary ikan yang mencapai TKG IV. Cara mendapatkan telur yaitu dengan mengambil telur dari ikan betina dengan mengangkat seluruh gonadnya dari dalam perut ikan yang telah diawetkan. Fekunditas dapat dihitung dengan metode gravimetrik dengan rumus (Effendi, 1997) : 
$F=\left(\frac{G}{Q}\right) x N$

dimana:

$$
\begin{array}{ll}
\mathrm{F} & =\text { fekunditas } \\
\mathrm{N} & \text { = jumlah telur tiap gonad contoh } \\
\mathrm{G} & \text { = berat gonad (gram) } \\
\mathrm{Q} & \text { = gonad contoh (gram) }
\end{array}
$$

\section{HASIL DAN BAHASAN}

\section{Hasil}

\section{Hubungan Panjang-Berat}

Persamaan hubungan panjang-berat ikan selar bentong yang tertangkap di perairan Laut Sulawesi diperoleh nilai $\mathrm{a}=0,0092$; nilai $\mathrm{b}=3,18$ dan nilai $\mathrm{R}^{2}=$ 0,9059 . Dari hasil tersebut setelah di uji dengan uji-t di dapatkan $t_{\text {hitung }}<t_{\text {tabel }}$ hal ini berarti pola pertumbuhan bersifat isometrik. Hubungan panjang berat ikan selar bentong jantan dan betina disajikan pada Gambar 2 .

\section{Rasio Kelamin}

Perbandingan jenis kelamin selar bentong diperoleh rasio jantan terhadap betina yang berbeda pada setiap bulannya. Secara keseluruhan, perbandingan kelamin betina dan jantan adalah $1: 1.9$.Berdasarkan uji Chi-Square diperoleh hasil $\mathrm{X}^{2}=8,64 ; \mathrm{X}^{2}$ tabel $(0,05)=3,84, \mathrm{X}^{2}$ tabel $(0,01)=6,64$ yang berarti perbandingan jenis jantan dan betina berbeda nyata atau dalam keadaan tidak seimbang. Rasio kelamin bulanan disajikan pada Gambar 3.

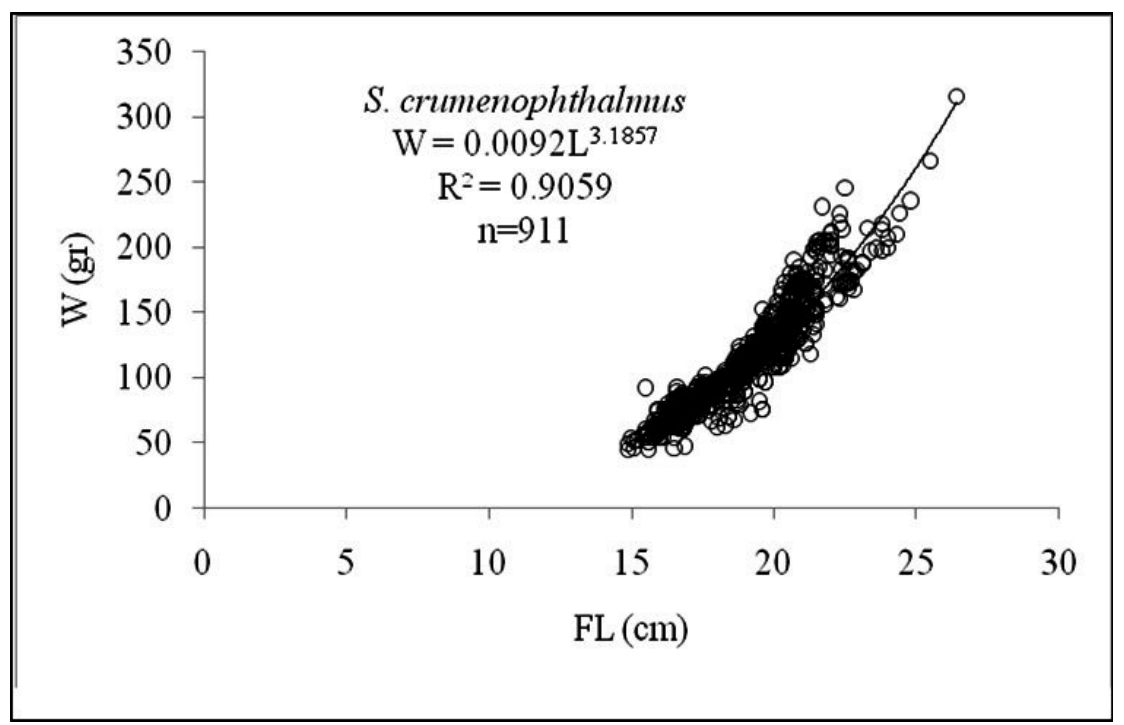

Gambar 2. Hubungan panjang berat ikan selar bentong gabungan yang tertangkap di perairan Kwandang tahun 2017. Figure 2. Length weight of bigeye scad caught in Kwandang waters 2017.

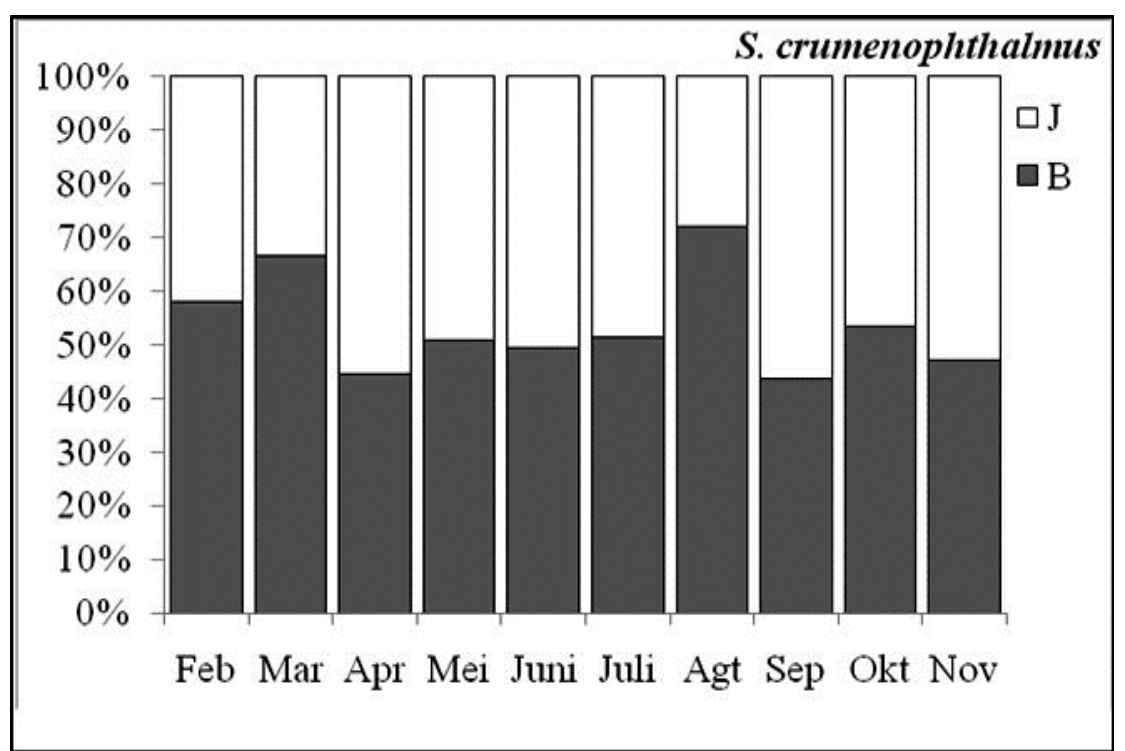

Gambar 3. Rasio kelamin ikan selar bentong yang tertangkap perairan Kwandang tahun 2017.

Figure 3. Sex ratio of bigeye scad caught in Kwandang waters 2017. 


\section{Tingkat Kematangan Gonad (TKG)}

Hasil pengamatan sampel ikan selar bentong selama tahun 2016 berbeda pada setiap bulannya. Hasil pengamatan TKG bulanan disajikan pada Gambar 4. Terdapat perubahan komposisi TKG tiap bulannya. TKG
IV pada ikan selar bentong betina ditemukan pada bulan Februari sampai November dengan jumlah dominan terdapat pada bulan Agustus dan November, sedangkan untuk ikan selar bentong jantan, TKG IV dominan pada bulan Juni.

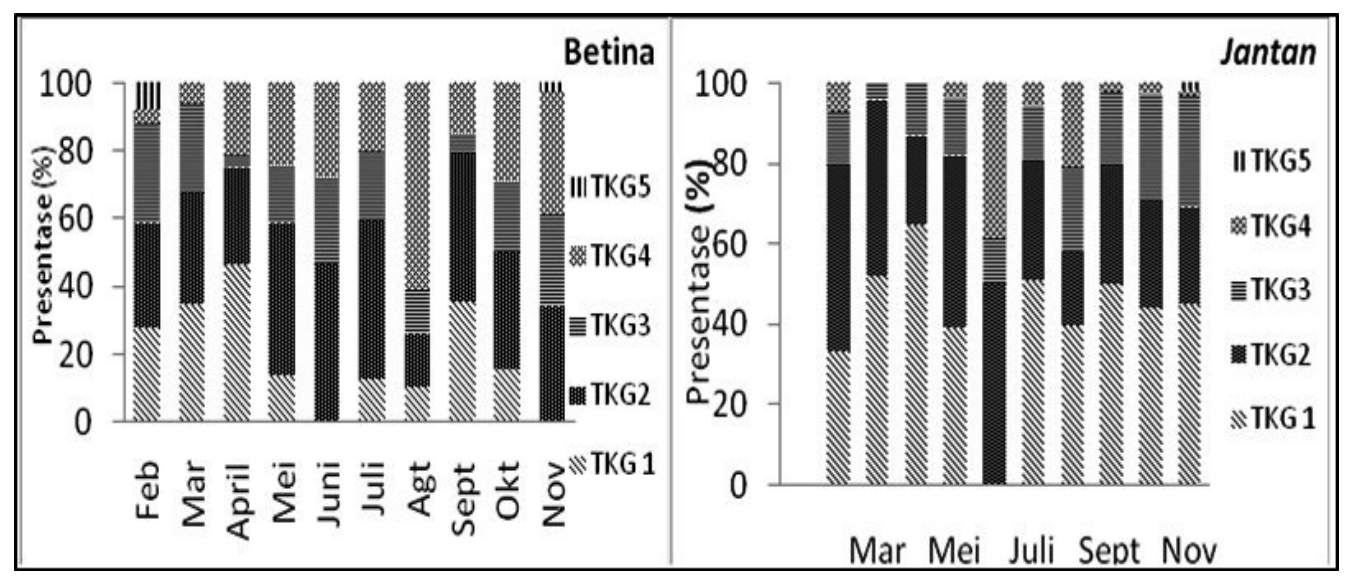

Gambar 4. Tingkat kematangan gonad ikan selar bentong yang tertangkap perairan Kwandang tahun 2017

Figure 4. Gonad Maturity stages of bigeye scad caught in Kwandang waters 2017.

\section{Panjang Pertama Kali Matang Gonad (Lm) dan Gonado Somatic Index (GSI)}

Berdasarkan analisis, panjang pertama kali matang gonad selar bentong dari perairan Laut Sulawesi adalah 17, 69 cmFL. Selanjutnya perhitungan GSI diperoleh nilai tertinggi pada bulan Oktober. Perubahan nilai GSI tersaji pada Gambar 5 .

\section{Fekunditas dan Diameter Telor}

Jumlah telor (fekunditas) ikan selar berkisar antara 148.897 - 472.237 butir. Hasil analisa diameter telor diperoleh sebaran diameter seperti disajikan pada Gambar 6. Diameter telor ikan selar berkisar antara 0,14 $-0,44 \mathrm{~mm}$.

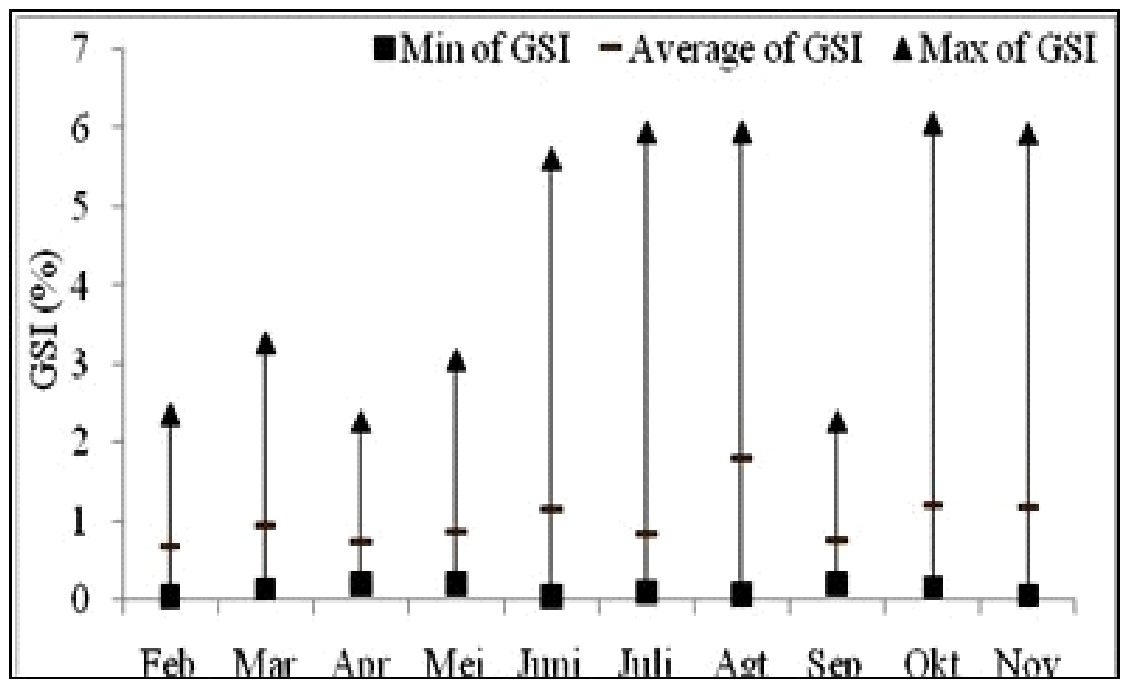

Gambar 5. Indeks kematangan gonad (IKG) ikanselar bentong yang tertangkap di perairan Kwandang tahun 2017.

Figure 5. Gonado Somatic Index of bigeye scad caught in Kwandang waters 2017. 


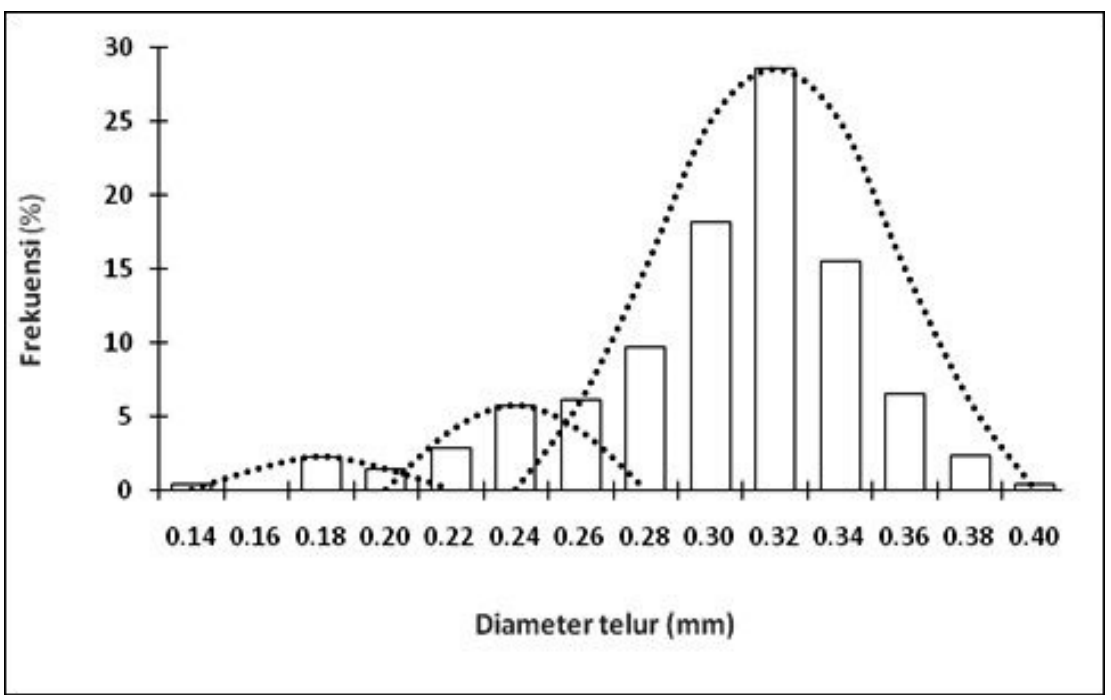

Gambar 6. Diameter telor ikan selar bentong yang tertangkap di perairan Kwandang.

Figure 6. The diameter of bigeye scad eggs caught in Kwandang waters.

\section{Bahasan}

Pola pertumbuhan ikan selar bentong (Selar crumenophthalmus) di perairan Kwandang, bersifat isometrik yang artinya bahwa pertambahan berat seiring dengan pertambahan panjangnya. Jika dibandingkan dengan beberapa penelitian mengenai pola pertumbuhan selar bentong di lokasi lain, hasilnya berbeda. Di perairan Semarang, pola pertumbuhan selar bentong bersifat allometric negativ (Siwat et al., 2016), sementara di perairan Teluk Manzanillo Meksiko pola pertumbuhan selar bentong bersifat allometrik positif (Barr et al., 2016). Menurut Tesch dalam ElHaweet (2013), variasi nilai b dapat disebabkan oleh beberapa faktor, seperti fase pertumbuhan, dampak musim, kisaran ukuran panjang, faktor kondisi relatif dan selektifitas ukuran tangkap. Kemudian Damora \& Wagiyo (2012) menambahkan perbedaan nilai $b$ pada hubungan panjang berat menunjukkan pertumbuhan yang bersifat relatif, artinya dapat berubah menurut waktu. Jenning et al. (2001), mengemukakan secara umum, nilai b tergantung pada kondisi fisiologis dan lingkungan seperti: suhu, $\mathrm{pH}$, salinitas, letak geografis dan teknik sampling. Froese, (2006) menyatakan kondisi biologis seperti perkembangan gonad dan ketersediaan makanan dapat mempengaruhi nilai $b$.

Menurut Siby et al. (2009) ukuran pertama kali matang gonad secara berkala dapat dijadikan indikator adanya tekanan terhadap populasi. Ukuran pertama kali matang gonad ikan selar bentong pada penelitian ini adalah 17,69 cmFL. Penelitian sebelumnya, Faizah et al. (2014) diperairan yang sama diperoleh nilai Lm 19,5 cmFL. Dengan demikian maka pada saat ini nilai Lm berubah yaitu makin kecil. Menurut (Lowe-McConnel 1995 Moresco \& de Bemvenuti, 2006) ukuran pertama kali matang gonad yang berbeda-beda merupakan strategi reproduksi ikan untuk memulihkan keseimbangan populasinya akibat adanya perubahan kondisi, faktor abiotik dan tangkap lebih. Nilai Lm pada penelitian ini juga lebih kecil daripada ikan bentong yang tertangkap di Laut Jawa yaitu $\mathrm{Lm}=18,7$ (Atmaja et al., 1995) serta di perairan Reunion, di Selatan Samudera Hindia yaitu 21,5 cm(Ross et al., 2007). Menurut Dahlan et al. (2015) ukuran dan umur ikan pada saat pertama kali matang gonad tidak sama antara satu spesies dan spesies lainnya. Bahkan, ikan-ikan yang berada pada spesies yang sama juga akan berbeda jika berada pada kondisi dan letak geografis yang berbeda.

Rasio kelamin ikan bentong betina terhadap jantan adalah $1: 1,2$. Berdasarkan uji Chi-Square diperoleh hasil $X^{2}=8,64 ; X^{2}$ tabel $(0,05)=3,84, X^{2}$ tabel $(0,01)=6,64$ yang berarti perbandingan jenis jantan dan betina berbeda nyata atau dalam keadaan tidak seimbang. Menurut Effendie(1997) rasio kelamin ikan di alam idealnya seimbang agar peluang untuk bereproduksi tinggi dan ideal untuk mempertahankan spesies. Selanjutnya Senen et al. (2011) menambahkan keseimbangan jumlah ikan jantan dan betina mengindikasikan satu ikan bentong jantan akan membuahi satu ikan bentong betina. Rasio kelamin ini tidak berbeda jauh dengan rasio kelamin hasil penelitian Zamroni \& Suwarso (2011) di perairan Laut Banda yaitu $1: 1,44$.

Waktu pemijahan pada ikan dapat diduga dengan melihat komposisi tingkat kematangan gonadnya. Kondisi TKG IV (matang gonad) ikan selar bentong betina mencapai puncaknya pada bulan Agustus dan November, sedangkan ikan selar bentong jantan, pada bulan Juni. TKG V ditemukan pada bulan November-Februari (Gambar 4). Diindikasikan pada bulan tersebut ikan selar dalam kondisi memijah dimana kondisi ovarium mengerut dan 
berisi sisa pelepasan butir-butir telur yang opaque dan yang matang (Holden \& Raitt, 1974). Menurut Ozvarol et al. (2010) musim atau waktu pemijahan terjadi ketika nilai indeks kematangan gonad (IKG) untuk kedua jenis kelamin mencapai tingkat tertinggi. Berdasarkan kondisi perkembangan TKG dan IKG tersebut, dapat diduga bahwa pematangan gonad ikan selar bentong mncapai puncaknya dimulai dari bulan Agustus dan musim pemijahannya dimulai bulan November-Februari. Faizah et al. (2014), menyatakan bahwa musim pemijahan selar bentong di perairan Kwandang terjadi pada bulan November hingga Januari. Selanjutnya Atmaja et al. (1995) menyatakan bahwa puncak musim pemijahan Selar crumenophthalmus di Laut Jawa yang tertangkap purse seine diduga berlangsung sekitar musim Barat (Desember-Februari). Menurut Zamroni \& Suwarso (2011), di perairan Laut Banda nilai indeks gonad Selar crumenophthalmus dengan nilai yang lebih tinggi terjadi pada musim Timur (Juni-Agustus). Kawamoto (1973) menyatakan bahwa musim pemijahan selar bentong di perairan Hawai terjadi antara bulan April hingga November. Sedangkan menurut DLNR (1979) menyatakan bahwa di perairan Hawai musim pemijahan terjadi antara bulan Februari hingga Agustus. Sementara itu, menurut Clarke \& Privitera (1995) menyatakan bahwa di perairan Hawai musim pemijahan terjadi antara April-Oktober. Ross et al. (2007) mengungkapkan bahwa proporsi ikan selar bentong dewasa di perairan Pulau Reunion, Selatan Samudera Hindia meningkat pada bulan Oktober dan musim pemijahan terjadi pada bulan November. Clarke \& Privitera (1995) juga menambahkan bahwa sepertinya ada variasi tahunan terkait musim pemijahan untuk selar bentong dan biasanya pemijahan terjadi saat fajar dan senja hari.

Fekunditas ikan selar bentong berkisar 148.897 472.237 butir telur. Fekunditas di perairan Kwandang lebih tinggi dibandingkan dengan perairan Hawaii yaitu berkisar antara 48.000 sampai 262.000 butir (Clarke \& Privitera, 1995). Menurut Effendi (2002) fekunditas dipengaruhi oleh makanan dan kondisi lingkungan perairan. Dengan demikian adanya perbedaan jumlah telur ikan selar bentong ini dimungkinkan karena perbedaan kondisi perairan, makanan serta ukuran ikan. Diameter telur ikan selar di perairan Kwandang berada pada kisaran antara $0,14-0,44 \mathrm{~mm}$ dan terdapat 3 modus penyebaran. Menurut Suwarso \& Sadhotomo (1995), ikan selar bentong di Laut Jawa berpijah lebih dari satu kali dalam satu musim pemijahan. Peneliti Iwai et al. (1996) menambahkan tipe pemijahan ikan selar bentong di perairan Hawaii adalah multiple spawner I yang memproduksi 96000 hingga 121.000 butir telur setiap memijah, 5 hingga 10 kali per tahun. Roux dan Conand (2000) menyatakan bahwa $S$. crumenophthalmus memiliki siklus reproduksi tahunan dan pemijahan terjadi sebagian besar dari Oktober hingga Desember.

\section{KESIMPULAN}

Pola pertumbuhan ikan selar bentong Selar crumenophthalmus di perairan Kwandang bersifat isometrik. Ukuran pertama kali matang gonad semakin mengecil dari tahun sebelumnya $(\mathrm{Lm}=17,69 \mathrm{cmFL})$. Rasio kelamin ikan selar betina terhadap jantan dalam keadaan tidak seimbang. Musim pemijahan ikan selar bentong diperkirakan terjadi pada bulan November-Februari.

\section{PERSANTUNAN}

Tulisan ini merupakan bagian dari kegiatan penelitian "Karakteristik biologi perikanan, habitat sumber daya ikan dan potensi produksi sumberdaya perikanan di WPP716 (Laut Sulawesi dan sebelah Utara Pulau Halmahera)" pada Balai Penelitian Perikanan Laut Muara Baru, Jakarta tahun anggaran 2016. Penulis mengucapkan terima kasih kepada petugas enumerator di PPN. Kwandang yang telah membantu dalam pengumpulan data selama penelitian.

\section{DAFTAR PUSTAKA}

Atmaja, S. B., Sadhotomo, B., \& Suwarso. (1995). Reproduction of main small pelagic species in Java Sea. Workshops Biology, Dynamic, and Exploitationof Small Pelagic in Java Sea, 69-84.

Clarke, T.A. \& L.A. Privitera. (1995). Reproductive biology of two Hawaiian pelagic carangid fishes, the bigeye scad, Selar crumenophthalmus, and the round scad, Decapterus macarellus. Bulletin Marine. Science, 56:33-47.

Damora, A \& K. Wagiyo. (2012). Parameter populasi ikan kadah (Valamugil) (speigleri) sebagai indikator pemanfaatan sumber daya perairan estuaria di Pemalang. Bawal, 4 (2), 91-96. DOI: http://dx.doi.org/ $\underline{10.15578 / \mathrm{bawal} .4 .2 .2012 .91-96}$

Dahlan, M.A., Omar, S.B.A., Tresnati, J., Umar, M.T., \& Nur, M. (2015). Nisbah kelamin dan ukuran pertama kali matang gonad ikan layang deles (Decapterus macrosoma Bleeker, 1841) di Perairan Teluk Bone, Sulawesi Selatan. Torani (Jurnal Ilmu Kelautan dan Perikanan), 25 (1), 25-29.

Department of Land \& Natural Resources (DLNR), State of Hawaii. (1979). Hawaii Fisheries Development Plan. $37 \mathrm{p}$.

De Robert \& William, A. K. (2008). Weight-length relationship in fisheries studies: the standard allometric model should be applied with caution. Transaction of the American Fisheries Society, 137, 707-719. 
ElHaweet, A.E.A. (2013). Biological studies of the invasive species Nemipterus japonicus (Bloch, 1791) as a Red Sea immigrant into the Meditteranian. Egyptian Journal of Aquatic Research, 39, 267-274.

Effendie, I. M. (1997). Biologi Perikanan (p.163). Yayasan Pustaka Nusatama..

Efendie IM. (1979). Metoda Biologi Perikanan (p.112). Yayasan Dewi Sri.

Everhart, W.H. \& Youngs, W.D. (1981). Principles of fishery Science (p. 349). 2nd Edition Comstock Publishing Associates, a division of Cornell University Press, London.

Faizah, R., Sadiyah, L. \& Hariati, T. (2014). Parameter populasi dan biologi reproduksi ikan bentong (Selar crumenophthalmus) di perairan Kwandang Gorontalo Utara. Bawal, 6 (2), 111-117.

DOI: http://dx.doi.org/10.15578/bawal.6.2.2014.111-117

Froese, R. (2006). Cube law, condition factor and weight length relationship: history, meta-analysis and recommendations. Journal of Applied Ichthyology, 22, 241253.

Jennings, S., Kaiser, M.J., \& Reynolds, J.D. (2001). Marine Fishery Ecology (p.417). Blackwell Sciences, Oxford.

Gulland, J.A. (1971). The Fish Resources of the Oceans (p. 209). Fishings News (Books) Ltd. Surrey, England.

Hidayat, T. (2005). Pembuatan hidrolisat protein dari ikan selar kuning (Caranx leptolepis) dengan menggunakan enzim papain. Program Studi Teknologi Hasil Perikanan Fakultas Perikanan dan Ilmu Kelautan Institut Pertanian Bogor. 70.

Holden, M.J. \& Raitt, D.F.S. (eds.), (1974). Manual of fisheries science. Part 2: Methods of resource investigation and their application. FAO Fish.Tech. Rep. 115 (Rev. 1) (p.214). Rome, Italy.

Iwai, T.Y., Tamaru, C. S., Yasukochi, L., \& Mitsuyasu, M. (1996).Natural spawning of captive bigeye scad Selar crumenophthalmus in Hawaii. Journal of the World Aquaculture Society, 27(3), 332-339.

Kawamoto, P.Y. (1973). Management investigation of the akule or bigeye scad, Trachurops crumenophthalmus (Bloch).Hawaii Division of Fish and Game, Project Report No.H-4-r, Honolulu, Hawaii, 28.
Kimura, S. (2011). Fishes of Terengganu. Proceeding of Carangidae Jacks (Scad, Trevallies).National Museum of Nature and science. Malaysia, 99.

Lowe-McConnell, R. H. (1995). Ecological studies in tropical fish communities (p. 382). Cambridge University Press, Cambridge.

Moresco, A. \& de Bemvenuti, A. (2006). Reproductive biology of silverside Odontesthes argentinensis (Valenciennes) (Atherinopsidae) of coastal sea region of the South of Brazil. Revista Brasiliera de Zoology, 23(4), 1168-1174.

Ozvarol, Z.A.B., Balci, B.A., Tasli, M.G.A., Kaya Y., \& Pehlivan, M. (2010). Age, growth, and reproduction of goldband goatfish (Upeneus moluccensis Bleeker (1855) from the Gulf of the Antalya (Turkey). Journal of Animal and Veterinary Advances, 9(5), 939-945.

Roos, D., Roux, O., \& Conand, F. (2007). Notes on the biology of the bigeye scad, Selarcrumenophthalmus (Carangidae) around ReunionIsland, southwest Indian Ocean. SCIENTIA MARINA, Barcelona (Spain), (71), 137-144.

Roux, O., \& Conand, F. (2000). Feeding habits of the bigeye scad, Selar crumenophthalmus (Carangidae), in La Reìunion Island waters (south-western Indian Ocean). Cybium, 24 (2), 173- 179.

Siwat, A., Ambariyanto, \& Widowati, I. (2016). Biometrics of bigeye scad, Selarcrumenophthalmus and shrimp scad, Alepesdjedaba from Semarang waters, Indonesia. AACL Bioflux, 9 (4), http://www.bioflux.com.ro/aacl.

Siby, L. S., Rahardjo, M. F., \& Sjafei, D. S. (2009). Biologi reproduksi ikan pelangi merah (Glossolepis incisus weber, 1907) di Danau Sentani. Jurnal Iktiologi Indonesia, 9(1), 49-61.

Senen, B., Sulistiono., \& Muchsin, I. (2011). Beberapa aspek biologi ikan layang deles (Decapterus macrosoma) di perairan Banda Neira, Maluku. Prosiding Seminar Nasional. Pengembangan Pulaupulau Kecil. 52-60.

Statistik PPN Kwandang. (2016). Laporan statistik perikanan tangkap pelabuhan perikanan Nusantara Kwandang. Direktorat Jenderal Perikanan Tangkap. Kementerian Kelautan dan Perikanan. 66.

Suwarso \& Sadhotomo, B. (1995). Studi biologi reproduksi dan komponen kohor ikan bentong (Selar crumenophthalmus) famili Carangidae di Laut Jawa. 
Disampaikan dalam Seminar Ilmiah dan Kongres Nasional Biologi XI. Bogor, 24 - 27 Januari. 1995. 15.

Suwarso, Kuswoyo, A., \& Fauzi, M. (2013). Ekspoitasi ikan pelagis kecil di Laut Sulawesi. Bunga Rampai Status Pemanfaatan Sumber Daya Ikan di perairan Laut Jawa dan Laut Sulawesi. BPPL. 95-108.

Syam, A.R. (2006). Parameter stok dan laju eksploitasi ikan kawalinya (Selar crumenophthalmus) di Peraian Maluku. Prosiding Seminar Nasional Ikan IV. 51-62.

Udupa, K. S. (1986). Statistical method of estimating the size of first maturity in fish. Fishbyte ICLARM. Manila. $4(2) .8-1$.
Widodo, J. (1989). Roproductive biology and harvestingstrategy of Indian scad, Decapterus russelli (Ruppell, 1830), (Pisces: Carangidae) of the Java Sea. Jurnal Penelitian Perikanan Laut, 53, 89-96.

Widodo, J., Suwarso, \& Suryono, H. (1993). Biologireproduksi dan perikanan selar bentong, Selarcrumenophthalmus (Carangidae), di Laut Jawa. Jurnal Penelitian Perikanan Laut, 72, 1-9.

Zamroni, A. \& Suwarso. (2011). Studi tentang biologi reproduksi beberapa species ikan pelagis kecil di perairan Laut Banda. BAWAL, 3 (5),337-344. DOI: http://dx.doi.org/10.15578/bawal.3.5.2011.337-344 